\title{
Physicochemical properties and isoflavone content of Chaga Cheonggukjang with Lactobacillus acidophilus KCTC 3925 starter
}

\author{
Ha Gyoon $\mathrm{Na}^{1}$, Eun Ho Jang ${ }^{1}$, Dong Hun $\mathrm{Nam}^{1}$, Min-Ah Kim ${ }^{1}$, Mi-Ja Kim${ }^{1}$, \\ Eun Hwa Sohn ${ }^{2}$, Hyun Dong Kim³ ${ }^{3}$ Ki-Hyo Jang ${ }^{1 *}$ \\ ${ }^{1}$ Department of Food and Nutrition, Kangwon National University, Samcheok 25949, Korea \\ ${ }^{2}$ Department of Herbal Medicine Resource, Kangwon National University, Samcheok 25949, Korea \\ ${ }^{3}$ Bari Co., Ltd., Donghae 25800, Korea
}

\section{Lactobacillus acidophilus KCTC 3925균을 종균으로 사용한 차가버섯 청국장의 품질특성 및 isoflavone 함량 변화}

\author{
나하균 $^{1} \cdot$ 장은호 $^{1} \cdot$ 남동훈 $^{1} \cdot$ 김민아 $^{1} \cdot$ 김미자 $^{1} \cdot$ 손은화 $^{2} \cdot$ 김현 동 $^{3} \cdot$ 장기효 $^{1 *}$ \\ ${ }^{1}$ 강원대학교 식품영양학과, ${ }^{2}$ 강원대학교 생약자원개발학과, ${ }^{3}$ (주)바리의꿈
}

\begin{abstract}
This study was conducted to investigate the quality characteristics and changes in isoflavone content of Cheonggukjang with added Chaga mushroom by secondary fermentation at $40^{\circ} \mathrm{C}$ for $48 \mathrm{~h}$ with or without a starter, Lactobacillus acidophilus KCTC 3925. Cheonggukjang samples were divided into three groups: Control (unsterilized Cheonggukjang fermented without a starter), NS (unsterilized Cheonggukjang inoculated with L. acidophilus KCTC 3925), and YS (heat-sterilized Cheonggukjang inoculated with $L$. acidophilus KCTC 3925). The approximate composition of the three types of Cheonggukjang was $49.79-51.44 \%$ moisture, $4.54-4.72 \%$ crude ash, $43.21-44.37 \%$ crude protein, 11.58-13.65\% crude fat, 37.41-40.07\% carbohydrate, 31.92-33.82\% dietary fiber. The mineral content included 5.439.64 mg\% Na, 1,792.86-1,824.39 mg\% K, 253.69-326.09 mg\% Ca, 619.37-691.20 mg\% P, 92.59-110.59 mg\% Fe, and 0.01-0.02 mg\% Cd. Free amino acid contents of NS (2,520.92 mg\%) and YS (2,421.94 mg\%) were significantly higher than that of the control $(2,236.76 \mathrm{mg} \%)$. Amino-type nitrogen content for the three types of Cheonggukjang ranged from 837.20-920.27 $\mathrm{mg} \%$ with no significant difference. Ammonia-type nitrogen content ranged from 137.09-169.36 mg\%. Supplement of Cheonggukjang with $L$. acidophilus KCTC 3925 increased production of aglycone isoflavons compared to that of control. Therefore, our results show that fermenting Chaga Cheonggukjang with L. acidophilus KCTC 3925 leads to improved quality characteristics and increased isoflavone aglycone content.
\end{abstract}

Key words : Chaga Cheonggukjang, Lactobacillus acidophilus, physicochemical properties, isoflavone agylcone

\section{서 론}

청국장은 콩을 주원료로 하여 종균의 사용 없이도 자연 발효법에 의해 제조되는 발효식품으로 단백질, 탄수화물,

*Corresponding author. E-mail : kihyojang@kangwon.ac.kr Phone : 82-33-540-3312, Fax : 82-33-540-3319

Received 13 March 2018; Revised 2 April 2018; Accepted 4 April 2018.

Copyright (c) The Korean Society of Food Preservation. All rights reserved.
지방 등의 필수 영양소의 함량이 높고, 이 외에 생리활성 물질도 다량 함유되어 있다 $(1,2)$. 청국장은 대두발효 식품 류 중 가장 짧은 기일에 완성할 수 있으면서 원료 대두가 갖는 영양기능, 감각기능이외에도 여러가지 생체조절기능 을 나타내는 이유로 청국장의 기능성에 관한 연구가 활발하 게 진행되고 있다(3). 현재 알려진 청국장의 기능성으로는 혈전 용해능, 혈압 및 지질대사 개선효과, 항암효과, 항산화 효과(4) 등 다양한 보고가 있다. 청국장은 발효되면서 대두 의 단백질, 탄수화물 및 지방질이 소화되기 쉬운 상태로 분해되어 소화 흡수율이 증가하고(5), 특히 대두에 존재하 
는 isoflavone은 유방암, 대장암, 자궁암 등의 억제효과가 탁월하고 동맥경화 및 $\mathrm{LDL}$ 콜레스테롤 감소, 골다공증 등 만성 질환의 예방효과가 높다고 보고되었지만, 대부분 배 당체로 존재하여 체내흡수율이 매우 낮아 식품으로 섭취하 기 위해서는 장내세균에 의해 비배당체로 전환된 후 체내에 흡수되어야 한다. 하지만 대두를 발효시킨 청국장에서는 발효과정 중 미생물의 $\beta$-glucosidase에 의해 비배당체 형태 로 전환되어 체내에서 배당체 형태보다 빠르게 흡수된다. 일부 유산균들도 이소플라본 배당체를 비배당체로 전환하 는 것으로 알려져 있다. Kiyosawa 등(6)은 Bifidobacterium longum을 이용하여 제조한 대두 요구르트 이소플라본의 대부분이 aglycone으로 전환되었다고 보고하고 있으며, Donkor와 Shah(7)의 보고에서는 Lactobacillus acidophilus 를 넣어 36시간 발효시킨 두유에서 가장 이소플라본 비배 당체 함량이 많았다고 보고하고 있다. 이처럼 이소플라본 의 낮은 체내 흡수율을 보완하기 위해서는 이소플라본을 비배당체 형태로 전환하는 생물전환 공정 기술 및 가공기술 이 필요하다(8). 본 연구실에서는 식품에 사용이 허가된 Generally Recognized As Safe(GRAS) 미생물 중에서 된장 제조 시 비배당체 이소플라본 함량을 높여주는 $\beta$ -glucosidase 활성이 높은 유산균을 선별한 바가 있다(9). 최근 품질 및 기능성의 향상을 위해 식물성 천연소재인 배추(10), 다시마(11), 감초(12), 녹차(13), 키토산(2) 등을 첨가한 청국장들이 보고되고 있다. 차가버섯(Inonotus obliquus)은 소나무 비늘버섯과(Hymenochaetaceae)에 속하 는 약용 버섯으로, 주로 북위 45 도 이상의 러시아를 비롯한 한랭지역에서 자생하는 검은 자작나무, 오리나무, 물푸레 나무 등에 기생하는 균핵이다. 주로 약용으로 이용되며, 주요 성분으로는 triterpene, polysaccarides, isoprenoid, polyphenol, lignin, magnesium, lanosterol, obliquol 등이 있 다(14). 차가버섯은 비만 및 지질대사 개선, 콜레스테롤 저 하효과를 보이기도 하며, 항산화 작용, 혈전용해 및 혈소판 응집억제, 항당뇨, 항 바이러스 등과 같은 기능성을 가지고 있어 이를 활용하여 주류 및 음료류, 과자 및 빵류, 국수류, 두부 등을 제조하고 있다(15).

이에 본 연구에서는 청국장의 기능성 향상을 위해 차가 버섯을 첨가한 청국장에 선행연구에서 $\beta$-glucosidase 활성 이 가장 우수하였던 유산균을 접종하여 2차 발효시켜 이러 한 첨가물들이 청국장의 품질특성에 미치는 영향을 조사하 였고, isoflavone 비배당체 함량 증가여부를 확인하였다.

\section{재료 및 방법}

\section{재료 및 청국장 제조}

본 연구에서 사용된 청국장은 강원도 동해시에 위치한 (주바리의 꿈으로부터 말린 차가버섯 청국장을 제공받아
사용하였고, 선행연구(9)에서 $\beta$-glucosidase 활성이 우수한 균으로 확인된 Lactobacillus acidophilus KCTC 3925균(이 하 $L$ acidophilus)을 MRS Broth(Difco, Sparks, MD, USA)를 이용하여 $37^{\circ} \mathrm{C}$ 에서 24 시간 정치배양한 후 종균으로 사용하 였다. 제공 받은 차가버섯 청국장 $20 \mathrm{~g}$ 에 증류수 $10 \mathrm{~mL}$, 50 배 희석된 lactic acid를 $7 \mathrm{~mL}$, 설탕물(50\%)을 최종농도가 $2.5 \%$ 가 되게끔 혼합된 차가버섯 첨가 청국장 시료 조성을 조절하였다. 이 시점에서 혼합된 차가버섯 첨가 청국장 시 료를 3 개군(control, NS, YS)으로 분배하였다. 3 개군에서 $\mathrm{YS}$ 군은 접종하기 전 시료를 열처리 $\left(100^{\circ} \mathrm{C}, 15 \mathrm{~min}\right)$ 하였으 며, control군과 NS군에서는 열 살균공정을 적용하지 않았 다. YS군과 NS군은 배양한 $L$ acidophilus균을 배양액 총량 대비 $5 \%$ 수준으로 종균을 접종하였으며, control군에서는 종균을 사용하지 않았다. 이상과 같이 발효액 조성과 열처 리 살균 공정을 달리한 3 개 시료들을 $40^{\circ} \mathrm{C}$ 로 설정된 배양기 (SI-4000R Jeio Tech, Daejeon, Korea)에서 48시간 동안 2차 발효하였으며, 발효 후 동결건조하여 분석에 사용하였다.

\section{물 추출물 제조}

2차 발효한 청국장 분말 $5 \mathrm{~g}$ 에 증류수 $45 \mathrm{~mL}$ 를 첨가하고 균질화한 후 1 시간 정치추출 하였다. 이를 원심분리기 (5816R, Eppendorf, Hamburg, Germany)로 2,800 rpm에서 10 분간 원심분리하여 얻은 상등액을 시료로 사용하였다.

\section{일반성분 분석}

수분은 동결건조 전과 후의 무게 차이로 분석하였으며, 수분을 제외한 나머지 청국장의 일반성분은 동결건조 된 시료로 $\mathrm{AOAC}(16)$ 방법에 따라 측정하였다. 조회분은 건식 회화법, 조지방은 Soxhlet 추출법, 조단백질은 micro-Kjeldahl 질소 정량법에 따라 측정하였다. 탄수화물은 100-(조단백+ 조지방+조회분)의 식을 이용하여 값을 표시하였다. 식이섬 유 함량 측정을 위하여 동결 건조된 청국장 시료에 효소들 (amylase, protease, amyloglucosidase)을 처리하여 전분과 단백질을 제거하고 ethanol을 사용한 침전, 여과, 건조 후 함량 측정 등의 공정을 실시하였으며, 잔존하는 조회분과 조단백질을 측정한 값을 차감하여 식이섬유 함량을 분석하 였다. $\mathrm{pH}$ 측정을 위하여 청국장 시료에 증류수를 $1: 9$ 의 비 율로 가하여 희석한 후 상층액을 회수하였다. 회수한 상층 액에 $\mathrm{pH}$ meter(model 725p, Istek, Seoul, Korea)를 이용하여 측정하였다.

\section{무기질 함량 측정}

무기질 함량 측정은 Koh 등(17)의 방법에 따라 측정하였 다. 동결 건조된 시료에 $\mathrm{H}_{2} \mathrm{O}_{2} 2 \mathrm{~mL}$ 와 $\mathrm{HNO}_{3} 7 \mathrm{~mL}$ 를 가한 후 Microwave Digestion System(Ethos Touch control, Milestone Inc, Sorisole, Italy)을 사용하여 최대 $1,000 \mathrm{~W}$ 로 산 가수분해 하였다 $\left(200^{\circ} \mathrm{C}\right.$ 까지 10 분 $\rightarrow 200^{\circ} \mathrm{C}$ 에서 20 분 $\rightarrow$ 
$20^{\circ} \mathrm{C}$ 까지 70 분). 분해된 시료를 ICP-AES(Inductively Coupled Plasma-Atomic Emission Spectrometer, Vista-PRO, Varian, Belrose, Australia)에 주입하여 무기질 함량을 분석 하였다. 분석조건은 다음과 같다. Refected power $1.2 \mathrm{~kW}$, 이동상 argon, plasma flow $15 \mathrm{~L} / \mathrm{min}$, auxiliary gas flow 1.5 $\mathrm{L} / \mathrm{min}$, nebulizer gas flow $0.7 \mathrm{~L} / \mathrm{min}$ 의 조건으로 측정하였으 며, 각 원소 별 측정 파장은 $\mathrm{Na}(588.995-589.592 \mathrm{~nm}), \mathrm{K}$ (766.491-769.897 nm), Ca(393.366-396.847 nm), P(177.434 -213.618 nm), Fe(238.204-259.940 nm), Cd(214.439-226.502 $\mathrm{nm})$ 로 설정하였다.

\section{유리아미노산 분석}

청국장 시료의 유리아미노산 분석은 Koh 등(17)의 방법 에 따라 측정하였다. 유리아미노산 분석을 위해서는 시료 $0.5 \mathrm{~g}$ 에 $70 \%$ ethanol $50 \mathrm{~mL}$ 를 가하여 30 분 동안 추출하여 10 분간 방치하였다. 추출 후 $1,500 \mathrm{rpm}$ 에서 15 분간 원심분 리한 후 상등액을 진공농축 하고 $0.02 \mathrm{~N} \mathrm{HCl} 20 \mathrm{~mL}$ 로 용해 시켜 여과하였다. 유리아미노산 분석을 위해 여과액을 Ion exchange column $(4.6 \mathrm{~mm} \times 60 \mathrm{~mm}$, Hitachi-2622PF, Hitachi, Tokyo, Japan)이 장착된 아미노산 분석기(Hitachi L-8800 Amino acid, Hitachi)에 주입하였다. 이동상은 다양한 $\mathrm{pH}$ 를 가진 buffer(pH-SET, Kanto Chemicals INC, Tokyo, Japan)를 사용하여 아미노산을 분리한 뒤 반응코일에서 ninhydrin과 반응시켜 $440 \mathrm{~nm}, 570 \mathrm{~nm}$ 에서 흡광도를 측정하였다. 칼럼 온도는 $30-70^{\circ} \mathrm{C}$, 반응코일 온도는 $135^{\circ} \mathrm{C}$ 로 설정하였고 유리 아미노산의 시료주입량은 $20 \mu \mathrm{L}$, 유속 $0.35 \mathrm{~mL} / \mathrm{min}, 0.3$ $\mathrm{mL} / \mathrm{min}$ 을 사용하였다.

아미노태 질소 함량 및 암모니아태 질소 함량 측정

아미노태 질소 함량은 다음과 같이 측정하였다(18). 물 추출물 $5 \mathrm{~mL}$ 에 중성 formalin 용액 $20 \mathrm{~mL}$ 를 넣은 본 시험과 물 추출물 $5 \mathrm{~mL}$ 에 증류수 $20 \mathrm{~mL}$ 를 넣은 공시험에 $0.1 \mathrm{~N}$ $\mathrm{NaOH}$ 로 $\mathrm{pH}$ 8.3이 될 때까지의 적정한 양을 이용하여 아미 노태 질소함량을 측정하였다. 암모니아태 질소 함량은 phenol-hypochloride법(19)으로 측정하였다. 물 추출물 0.1 $\mathrm{mL}$ 에 용액 $\mathrm{A}$ (phenol $10 \mathrm{~g}$ and sodium nitroprusside dehydrate $0.05 \mathrm{~g}$ in distilled water $1 \mathrm{~L})$ 와 용액 $\mathrm{B}\left(\mathrm{Na}_{2} \mathrm{HPO}_{4} \cdot 12 \mathrm{H}_{2} \mathrm{O}\right.$ $9 \mathrm{~g}, \mathrm{NaOH} 6 \mathrm{~g}$ and $\mathrm{NaOCl} 10 \mathrm{~mL}$ in distilled water $1 \mathrm{~L}$ )를 각각 $1 \mathrm{~mL}$ 씩 넣은 후 $37^{\circ} \mathrm{C}$ 에서 20 분간 반응시켜 $630 \mathrm{~nm}$ 에 서 흡광도를 측정하였다. 암모니아태 질소 함량은 $(\mathrm{NH} 4)_{2} \mathrm{SO}_{4}$ 를 이용하여 작성한 표준곡선으로부터 산출하 였다.

\section{Isoflavone 분석}

청국장 시료의 isoflavone 함량 분석은 $\mathrm{Kim}$ 등(9)의 방법 에 따라 측정하였다. 동결건조 시킨 청국장 시료 $5 \mathrm{~g}$ 에 $80 \%$ ethanol $45 \mathrm{~mL}$ 를 넣어 24시간 정치추출하여 상등액을 0.45 $\mu \mathrm{m}$ 여과막으로 여과한 뒤 Eclipse $\mathrm{XDB}^{-\mathrm{C}_{18}}$ column $(4.6 \times 250 \mathrm{~mm}$ ID, Agilent Technologies, Santa Clara, CA, USA)이 장착된 Agilent $1200 \mathrm{HPLC}($ Agilent Technologies) 에 $20 \mu \mathrm{L}$ 를 주입하여 $254 \mathrm{~nm}$ 로 설정된 $\mathrm{UV}$ dectector에 검출 된 면적으로 정량분석하였다. 실험에 사용된 비배당체 isoflavone 표준물질들인 daidzein, glycitein, genistein 등은 Sigma- Aldrich사(St. Louis, MO, USA) 제품을 구입하여 사용하였다. 유산균을 활용하여 2 차 발효한 청국장의 isoflavone 중에서 비배당체 isoflavone 함량을 이들 표준물 질들의 retention time과 피크면적을 비교하여 정성 및 정량 분석하였다. 이동상은 용매 $\mathrm{A}\left(0.1 \%\right.$ acetic acid in $\left.\mathrm{H}_{2} \mathrm{O}\right)$, 용 매 $\mathrm{B}(0.1 \%$ acetic acid in acetonitrile)를 사용하였으며 유속 $1.2 \mathrm{~mL} / \mathrm{min}$ 에 용매 gradient는 $0 \mathrm{~min}, 25 \mathrm{~min}, 50 \mathrm{~min}, 55$ $\mathrm{min}, 70 \mathrm{~min}, 75 \mathrm{~min}, 80 \mathrm{~min}, 90 \mathrm{~min}$ 에 맞춰 93:7, 93:7, $85: 15,80: 20,75: 25,75: 25,65: 35,65: 35(\mathrm{v} / \mathrm{v})$ 의 비율로 하였 다.

\section{통계처리}

본 연구의 결과는 3회 반복하여 얻은 결과를 평균(mean) 과 표준편차(SD)로 표시하였으며 SPSS 23.0 통계 프로그램 을 사용하여 각 시료군간 차이를 $\mathrm{p}<0.05$ 수준에서 one-way ANOVA(analysis of variation)를 실시하고 Duncan's multiple range test로 유의적 차이를 분석하였다.

\section{결과 및 고찰}

일반성분 및 $\mathrm{pH}$

L. acidophilus를 첨가한 차가버섯 청국장의 일반성분 분 석 결과는 Table 1과 같다. L acidophilus균 배양액을 접종하 지 않은 대조군(control), L acidophilus균 배양액을 접종한 군(NS), $L$ acidophilus균 배양액을 접종하기 전 열처리 $\left(100^{\circ} \mathrm{C}\right.$, $15 \mathrm{~min})$ 하여 잡균을 제거한 군(YS)의 일반성분을 분석한 결과 동결건조 전 수분함량은 control군이 $51.44 \%, \mathrm{NS}$ 군이 $49.79 \%, \mathrm{YS}$ 군이 $49.83 \%$ 로 나타났으며 이는 $\mathrm{Kim}$ 등(20)이 측정한 청국장의 수분함량 결과(50.3-62.2\%)와 유사하였 다. 동결건조 된 시료로 측정한 조회분 함량은 control군이 $4.57 \%, \mathrm{NS}$ 군이 $4.72 \%, \mathrm{YS}$ 군이 $4.54 \%$ 로 나타났고, 조단백 질 함량은 control군이 $44.37 \%, \mathrm{NS}$ 군이 $43.21 \%, \mathrm{YS}$ 군이 $43.82 \%$ 로 유의적인 차이가 없었다. 조지방 함량은 control 군이 $13.65 \%, \mathrm{NS}$ 군이 $12.60 \%, \mathrm{YS}$ 군이 $11.58 \%$ 로 control군 이 유의적으로 높았는데, 유산균으로 2 차 발효를 하였을 때 유의적으로 감소함을 관찰할 수 있었다 $(\mathrm{p}<0.05)$. 탄수화 물 함량은 control군이 $37.41 \%, \mathrm{NS}$ 군이 $39.47 \%, \mathrm{YS}$ 군이 $40.07 \%$ 로 유의적으로 control군이 낮게 관찰되었다 $(\mathrm{p}<0.05)$. Park 등 $(21)$ 이 측정한 동결 건조시킨 청국장의 일반성분과 비교하였을 때 조단백질 함량 $(50.45 \%)$, 조회분 
함량 $(4.66 \%)$ 은 유사하였으나 조지방 함량(23.47\%)과 탄수 화물 함량 $(14.63 \%)$ 에서 차이가 나타났다. 이는 청국장의 원료 대두의 차이에 의해 나타난 것으로 사료된다. 식이섬 유 함량은 control군이 $33.82 \%, \mathrm{NS}$ 군이 $31.92 \%$, YS군이 $32.63 \%$ 로 유의적인 차이가 없었다. 3 종의 청국장 시료들은 2차 발효전에 유산을 추가적으로 첨가하여 2차 발효하였으 므로 일반적인 청국장에서 보고된 $\mathrm{pH}$ 인 6.5-7.0과 비교시 상당히 낮은 수준의 $\mathrm{pH}$ 가 관찰되었다. 인위적인 $\mathrm{pH}$ 조절에 도 불구하고, 2 차 발효후에는 유산균을 사용한 시료들에서 대조군(control) 대비 유의적인 수준에서 $\mathrm{pH}$ 감소로 나타났 다(Table 1). pH는 NS, YS, control의 순으로 나타났으며, 이러한 결과는 NS와 YS 시료들에서 유산균에 의한 2 차 발효가 진행되었음을 나타낸다.

Table 1. Proximate composition and $\mathrm{pH}$ of Chaga Cheonggukjang added with $L$. acidophilus KCTC 3925

$(\%)$

\begin{tabular}{cccc}
\hline \multirow{2}{*}{ Proximate composition } & \multicolumn{3}{c}{ Samples $^{1)}$} \\
\cline { 2 - 4 } & Control & NS & YS \\
\hline Moisture & $51.44 \pm 0.36^{22 \mathrm{a} 3)}$ & $49.79 \pm 0.27^{\mathrm{b}}$ & $49.83 \pm 0.57^{\mathrm{b}}$ \\
Crude ash & $4.57 \pm 0.08^{\mathrm{b}}$ & $4.72 \pm 0.07^{\mathrm{a}}$ & $4.54 \pm 0.02^{\mathrm{b}}$ \\
Crude protein & $44.37 \pm 0.48$ & $43.21 \pm 0.54$ & $43.82 \pm 1.11$ \\
Crude fat & $13.65 \pm 0.68^{\mathrm{a}}$ & $12.60 \pm 0.49^{\mathrm{b}}$ & $11.58 \pm 0.28^{\mathrm{c}}$ \\
Carbohydrate & $37.41 \pm 1.01^{\mathrm{b}}$ & $39.47 \pm 0.86^{\mathrm{a}}$ & $40.07 \pm 1.19^{\mathrm{a}}$ \\
Dietary fiber & $33.82 \pm 1.13$ & $31.92 \pm 0.81$ & $32.63 \pm 1.49$ \\
pH & $5.45 \pm 0.03^{\mathrm{a}}$ & $4.77 \pm 0.01^{\mathrm{c}}$ & $4.88 \pm 0.00^{\mathrm{b}}$ \\
\hline
\end{tabular}

${ }^{1)}$ Control, fermented without sterilization process and a starter; NS, fermented without sterilization process but with a starter ( $L$ acidophilus KCTC 3925 ); YS, fermented with $L$ acidophilus $\mathrm{KCTC} 3925$ after sterilization process (at $100^{\circ} \mathrm{C}$ for $15 \mathrm{~min}$ ). ${ }^{2)}$ All values are mean $\pm \mathrm{SD}(\mathrm{n}=3)$.

${ }^{3)}$-c Means with different superscripts in the same row are significantly different at $\mathrm{p}<0.05$ by Duncan's multiple range test.

\section{무기질 함량}

Table 2는 무기질 함량을 측정한 결과로 칼슘은 control군 이 $275.16 \mathrm{mg} \%$, NS군이 $326.09 \mathrm{mg} \%$, YS군이 $253.69 \mathrm{mg} \%$, 인은 control군이 $691.20 \mathrm{mg} \%, \mathrm{NS}$ 군이 $676.44 \mathrm{mg} \%, \mathrm{YS}$ 군 이 $619.37 \mathrm{mg} \%$, 칼륨은 control군이 $1,792.86 \mathrm{mg} \%, \mathrm{NS}$ 군이 $1,824.39 \mathrm{mg} \%$, YS군이 $1,813.09 \mathrm{mg} \%$, 나트륨은 control군 이 $5.43 \mathrm{mg} \%, \mathrm{NS}$ 군이 $9.64 \mathrm{mg} \%$, YS군이 $7.75 \mathrm{mg} \%$ 로 나타 났다. 칼슘과 칼륨은 국가표준 식품성분표 제9개정판(22) 에서 명시되어 있는 청국장 가루의 칼슘, 칼륨양이 각각 $207 \mathrm{mg} \%, 1,665 \mathrm{mg} \%$ 인 것에 비해 본 시료들의 칼슴, 칼륨 함량이 높았으며 특히 NS군의 경우 칼슘 1.57 배, 칼륨 1.09 배 높았다. 이러한 무기질 함량의 차이는 국산콩과 본 과제 에서 사용한 러시아 연해주 산 콩의 차이로 판단된다. 칼슘 과 인은 $1: 1$ 의 비율로 섭취하였을 때 체내에서 가장 좋은 흡수율을 나타낸다. 각 시료별 칼슘과 인의 비율은 control
군이 2.51:1, NS군이 2.07:1, YS군이 2.44:1로 나타나 유산균 의 첨가는 칼슘과 인의 흡수율을 높여주는 것으로 나타났 다. 나트륨 함량은 국가표준 식품성분표 제9개정판(22)에 명시되어 있는 청국장 가루의 나트륨 함량은 $2,487 \mathrm{mg} \%$ 로 나트륨 함량에서 차이가 나는 이유는 시판 청국장의 경우 저장성을 늘리기 위해 $1-11 \%$ 의 소금량을 유지하고 있지만 (23), 본 연구에서 시료로 사용된 청국장에는 소금을 첨가하 지 않았기 때문이다. 철의 경우 control군은 $110.59 \mathrm{mg} \%$, $\mathrm{NS}$ 군은 $98.98 \mathrm{mg} \%$, YS군은 $92.59 \mathrm{mg} \%$ 로 측정 되었다. 카드뮴은 control $0.01 \mathrm{mg} \%$, NS $0.01 \mathrm{mg} \%$, YS $0.02 \mathrm{mg} \%$ 로 농산물의 카드뮴 허용수치인 $0.02 \mathrm{mg} \%$ (24)를 초과하지 않 았다.

Table 2. Mineral contents of Chaga Cheonggukjang added with L. acidophilus KCTC 3925

\begin{tabular}{cccc}
\hline \multirow{2}{*}{ Mineral } & \multicolumn{3}{c}{$(\mathrm{mg} \%)$} \\
\cline { 2 - 4 } & Control & NS & YS \\
\hline $\mathrm{Ca}$ & $275.16 \pm 0.28^{2 \mathrm{bb3})}$ & $326.09 \pm 0.57^{\mathrm{a}}$ & $253.69 \pm 0.31^{\mathrm{c}}$ \\
$\mathrm{P}$ & $691.20 \pm 2.84^{\mathrm{a}}$ & $676.44 \pm 5.67^{\mathrm{b}}$ & $619.37 \pm 5.37^{\mathrm{c}}$ \\
$\mathrm{K}$ & $1,792.86 \pm 20.32$ & $1,824.39 \pm 21.93$ & $1,813.09 \pm 17.38$ \\
$\mathrm{Na}$ & $5.43 \pm 0.09^{\mathrm{c}}$ & $9.64 \pm 0.13^{\mathrm{a}}$ & $7.75 \pm 0.10^{\mathrm{b}}$ \\
$\mathrm{Fe}$ & $110.59 \pm 0.15^{\mathrm{a}}$ & $98.98 \pm 0.05^{\mathrm{b}}$ & $92.59 \pm 0.17^{\mathrm{c}}$ \\
$\mathrm{Cd}$ & $0.01 \pm 0.00^{\mathrm{b}}$ & $0.01 \pm 0.00^{\mathrm{b}}$ & $0.02 \pm 0.00^{\mathrm{a}}$ \\
\hline
\end{tabular}

${ }^{1)}$ Control, fermented without sterilization process and a starter; NS, fermented without sterilization process but with a starter ( $L$ acidophilus KCTC 3925); YS, fermented with $L$ acidophilus KCTC 3925 after sterilization process (at $100^{\circ} \mathrm{C}$ for $15 \mathrm{~min}$ ). ${ }^{2)}$ All values are mean $\pm \mathrm{SD}(\mathrm{n}=3)$.

${ }^{33 a-c}$ Means with different superscripts in the same row are significantly different at $\mathrm{p}<0.05$ by Duncan's multiple range test.

\section{유리아미노산 함량}

청국장은 발효숙성 중 미생물의 작용으로 인해 원료콩 단백질이 분해되어 생성된 단맛을 내는 alanine, glycine, lysine, 쓴맛을 내는 valine, isoleucine, leucine, methionine 및 구수한 맛을 내는 aspartic acid, glutamic acid 등의 아미노 산이 어우러져 복합적인 청국장 특유의 맛을 형성한다고 알려져 있다(25). 본 연구의 유리아미노산 측정 결과는 단 맛, 쓴맛, 구수한 맛에 영향을 미치는 아미노산으로 나누어 Table 3에 나타내었다. Control군과 유산균을 접종한 NS군, YS군의 단맛(sweetness)을 내는 아미노산 함량은 각각 $518.02 \mathrm{mg} \%, 612.55 \mathrm{mg} \%, 592.07 \mathrm{mg} \%$ 로 나타났고 쓴맛 (bitterness)을 내는 아미노산 함량은 각각 $566.07 \mathrm{mg} \%$, $604.52 \mathrm{mg} \%, 603.90 \mathrm{mg} \%$ 로 나타나서 단맛, 쓴맛 모두 유산 균을 접종한 청국장에서 더 높게 나타났다. 또한 구수한 맛(savory taste)을 나타내는 아미노산 함량은 각각 671.13 $\mathrm{mg} \%, 714.68 \mathrm{mg} \%, 647.24 \mathrm{mg} \%$ 로 나타났지만 구수한 맛의 주요 물질인 glutamic acid의 총 아미노산에 대한 비율은 
각각 $22.86 \%, 21.95 \%, 21.09 \%$ 로 control군이 유산균을 접종 한 청국장 보다 유의적으로 높은 비율을 나타났다 $(\mathrm{p}<0.05)$. 이외의 맛(others)을 내는 아미노산 함량은 $481.53 \mathrm{mg} \%$, $589.17 \mathrm{mg} \%, 578.73 \mathrm{mg} \%$ 로 나타나서 단맛, 쓴맛과 마찬가 지로 유산균을 접종한 청국장에서 더 높게 나타났다. 본 연구에서는 glutamic acid, leucine, phenylalanine, alanine, aspartic acid 등의 함량이 높게 관찰되었다. Beak 등(26)은 발아 콩으로 제조한 청국장에서 glutamic acid, alanine 등의 함량이 높았으며, 시판 청국장 분말제품에서 유리아미노산 을 분석한 Lee 등(27)은 glutamic acid, valine, leucine, phenylalanine 등의 함량이 높았음을 보고하여 본 연구의 아미노산 조성과 유사한 경향을 나타내었다. 총 유리아미 노산 함량은 2,236.76 mg\%, 2,520.92 mg\%, 2,421.94 mg\%로 나타나서 유산균을 접종한 청국장에서 유의적으로 control 군, $\mathrm{NS}$ 군과 $\mathrm{YS}$ 군에서 각각 더 높게 나타났다 $(\mathrm{p}<0.05)$.

Table 3. Free amino acids contents of Chaga Cheonggukjang added with $L$. acidophilus KCTC 3925

\begin{tabular}{|c|c|c|c|c|}
\hline \multirow{2}{*}{\multicolumn{2}{|c|}{ Free Amino acids }} & \multicolumn{3}{|c|}{ Samples $^{1)}$} \\
\hline & & Control & NS & YS \\
\hline \multirow{6}{*}{ Sweetness } & Alanine & $179.11 \pm 1.42^{2 \mathrm{bb} 3)}$ & $201.76 \pm 5.43^{\mathrm{a}}$ & $210.58 \pm 9.97^{\mathrm{a}}$ \\
\hline & Glycine & $83.65 \pm 0.70^{\mathrm{b}}$ & $89.87 \pm 2.47^{\mathrm{ab}}$ & $95.87 \pm 4.77^{\mathrm{a}}$ \\
\hline & Lysine & $148.94 \pm 5.58^{c}$ & $198.78 \pm 5.08^{\mathrm{a}}$ & $169.35 \pm 14.32^{\mathrm{b}}$ \\
\hline & Serine & $49.56 \pm 0.15^{\mathrm{b}}$ & $58.71 \pm 1.68^{\mathrm{a}}$ & $56.58 \pm 3.27^{\mathrm{a}}$ \\
\hline & Threonine & $56.76 \pm 0.60^{\mathrm{b}}$ & $63.43 \pm 1.51^{\mathrm{a}}$ & $59.68 \pm 3.82^{\mathrm{ab}^{\mathrm{b}}}$ \\
\hline & Sum & $518.02 \pm 4.16^{\mathrm{c}}$ & $612.55 \pm 16.16^{\mathrm{a}}$ & $592.07 \pm 36.11^{\mathrm{b}}$ \\
\hline \multirow{6}{*}{ Bitterness } & Isoleucine & $103.41 \pm 3.54$ & $112.28 \pm 5.31$ & $113.35 \pm 6.31$ \\
\hline & Leucine & $279.16 \pm 10.52^{\mathrm{a}}$ & $258.11 \pm 5.85^{b}$ & $270.40 \pm 12.21^{\mathrm{ab}}$ \\
\hline & Methionine & $26.74 \pm 0.93^{\mathrm{b}}$ & $33.23 \pm 1.72^{\mathrm{a}}$ & $31.01 \pm 0.64^{\mathrm{a}}$ \\
\hline & Valine & $138.22 \pm 22.69$ & $178.15 \pm 6.50$ & $167.71 \pm 27.21$ \\
\hline & Histidine & $18.55 \pm 1.30^{b}$ & $22.74 \pm 0.70^{\mathrm{a}}$ & $21.43 \pm 2.46^{\mathrm{ab}}$ \\
\hline & Sum & $566.07 \pm 15.41^{\mathrm{c}}$ & $604.52 \pm 19.98^{\mathrm{a}}$ & $603.90 \pm 44.54^{b}$ \\
\hline \multirow{3}{*}{ Savory taste } & Aspartic acid & $159.88 \pm 1.13^{\mathrm{a}}$ & $161.35 \pm 4.49^{\mathrm{a}}$ & $136.63 \pm 13.78^{b}$ \\
\hline & Glutamic acid & $511.25 \pm 3.82^{\mathrm{b}}$ & $553.33 \pm 15.44^{\mathrm{a}}$ & $510.61 \pm 24.85^{\mathrm{b}}$ \\
\hline & Sum & $671.13 \pm 4.95^{\mathrm{ab}}$ & $714.68 \pm 19.92^{\mathrm{a}}$ & $647.24 \pm 38.63^{\mathrm{b}}$ \\
\hline \multirow{7}{*}{ Others } & Arginine & $4.29 \pm 0.07^{c}$ & $44.49 \pm 0.83^{\mathrm{a}}$ & $35.93 \pm 1.67^{b}$ \\
\hline & Ammonia & $110.56 \pm 2.07^{\mathrm{b}}$ & $146.97 \pm 4.85^{\mathrm{a}}$ & $153.48 \pm 8.05^{\mathrm{a}}$ \\
\hline & Proline & $58.48 \pm 0.83^{\mathrm{b}}$ & $78.30 \pm 2.40^{\mathrm{a}}$ & $80.45 \pm 3.18^{\mathrm{a}}$ \\
\hline & Phenylalanine & $247.74 \pm 14.97$ & $180.91 \pm 8.34$ & $257.64 \pm 13.38$ \\
\hline & Ornithine & $46.87 \pm 5.63$ & $46.15 \pm 1.35$ & $39.66 \pm 7.73$ \\
\hline & GABA & $13.59 \pm 6.80$ & $19.02 \pm 6.82$ & $11.57 \pm 4.78$ \\
\hline & Sum & $481.53 \pm 12.94^{\mathrm{b}}$ & $589.17 \pm 11.09^{\mathrm{a}}$ & $578.73 \pm 33.01^{\mathrm{a}}$ \\
\hline \multicolumn{2}{|c|}{ Total amino acid } & $2,236.76 \pm 14.59^{b}$ & $2,520.92 \pm 66.28^{\mathrm{a}}$ & $2,421.94 \pm 149.40^{\mathrm{ab}}$ \\
\hline \multicolumn{5}{|c|}{$\begin{array}{l}{ }^{11)} \text { Control, fermented without sterilization process and a starter, NS, fermented without } \\
\text { sterilization process but with a starter ( } L \text {. acidophilus KCTC } 3925) \text {; YS, fermented } \\
\text { with } L \text {. acidophilus KCTC } 3925 \text { after sterilization process (at } 100^{\circ} \mathrm{C} \text { for } 15 \text { min). } \\
{ }^{2)} \text { All values are mean } \pm \text { SD (n=3). } \\
\text { 3ac Means with different superscripts in the same row are significantly different at } p<0.05 \\
\text { by Duncan's multiple range test. }\end{array}$} \\
\hline
\end{tabular}

아미노태 질소 및 암모니아태 질소 함량

아미노태 질소함량과 암모니아태 질소함량을 측정한 결
과는 Table 4와 같다. 청국장의 아미노태 질소함량은 control 군에서 $920.27 \mathrm{mg} \%$, NS군에서 $884.80 \mathrm{mg} \%, \mathrm{YS}$ 군에서 $837.20 \mathrm{mg} \%$ 로 나타나 유의적인 차이가 없었다. Lee 등(28) 은 청국장에서 Bacillus subtilis MC31과 Lactobacillus sakei 383을 혼합 발효하였을 때 B. subtilis MC31을 단일 접종하 여 발효하였을 때와 비교시 아미노태 질소함량이 더 낮게 나타났다고 보고하고 있고, $\mathrm{Ju}$ 와 $\mathrm{Oh}(29)$ 는 B. subtilis 단일 균주로 배양한 청국장과 Lactobacillus plantarum과 혼합배 양한 청국장의 아미노태 질소함량은 별다른 차이가 없었다 고 보고하여 본 연구의 결과와 유사하였다. 전통장류에서 유래한 유산균주를 접종한 콩 발효물의 아미노태 질소 함량 을 측정한 Lee 등(30)도 유산균을 접종한 발효물 보다 접종 하지 않은 대조군이 더 높은 결과를 보였으며, 이는 발효과 정 중 생성 또는 분해되는 아미노산 생성량과 연관이 있을 것으로 설명하고 있다. 본 연구에 사용된 청국장의 유리아 미노산 중 구수한 맛의 지표인 glutamic acid의 비율을 살펴 보면 총 아미노산에 대한 비율이 control군은 $22.86 \%, \mathrm{NS}$ 군 은 $21.95 \%$, YS군은 $21.09 \%$ 로 나타나서 control군이 유산균 을 접종한 청국장보다 유의적으로 높았다. 따라서 위의 선 행연구 결과와 마찬가지로 발효에 따른 유리아미노산 변화 에 의해 아미노태 질소 함량에 차이가 나는 것으로 보여진 다. 아미노태 질소함량은 미생물의 작용에 의하여 단백질 이 아미노산의 형태로 분해되는 정도를 나타낸 것으로 된 장, 청국장 등의 장류 발효식품의 품질과 구수한 맛의 지표 로 사용되고 있다(31). 본 연구에서 유산균을 접종하였을 때 아미노태 질소함량이 감소하여 구수한 맛에 영향을 줄 것으로 예상된다. Lee 등(27)은 시판 청국장 분말제품의 아미노태 질소를 분석하여 $2.83-7.35 \%$ 의 범위를 나타낸다 고 보고하였다. 이 범위는 본 연구의 결과보다 낮은 범위를 나타내고 있어 유산균을 접종한 본 연구의 제품은 관능적인 품질 면에서 다른 시판 제품들에 비해 별 차이가 없다고 할 수 있다. 암모니아태 질소는 단백질 분해과정에서 탈아 미노반응에 의해 생성되며 함량이 증가할수록 이취와 함께 불쾌감을 주는 물질로 청국장의 변패 또는 이상발효를 나타 내는 지표로서 활용된다(32). 암모니아태 질소함량을 측정 한 결과 control군 $137.09 \mathrm{mg} \%, \mathrm{NS}$ 군 $145.31 \mathrm{mg} \%, \mathrm{YS}$ 군 $169.36 \mathrm{mg} \%$ 로 나타났다. $\mathrm{Ju}$ 와 $\mathrm{Oh}(29)$ 는 B. subtilis 균주와 L. plantarum을 혼합 배양한 청국장이 B. subtilis 균주로 단독 배양한 청국장보다 암모니아태 질소함량이 낮게 나타 났다고 보고하고 있으며, Lee 등(28)도 유산균을 혼합배양 하였을 때 암모니아태 질소함량이 낮게 나타났다. 본 연구 와 타 연구진들과의 결과의 상이함은 종균으로 사용한 유산 균의 차이 또는 발효과정의 차이에서 기인한다고 판단된 다. 하지만 타 연구진들이 보고한 암모니아태 질소의 범위 는 50.4-213.4 mg\%이므로 본 연구 결과(137.09-169.36 $\mathrm{mg} \%$ )는 범위안에 포함되었다. 본 연구에서 사용 된 청국장 의 발효 기간은 총 96시간으로 위의 선행연구에 쓰인 청국 
장의 발효기간보다 상대적으로 길었다. Eom 등(33)의 연구 에서 청국장의 발효기간이 늘어날수록 암모니아태 질소함 량이 증가하는 결과를 보였는데, 본 연구에서 적용한 상대 적으로 긴 발효시간에도 불구하고 다른 청국장들에 비해 본 연구에서 제조한 청국장의 불쾌취가 심하지 않다는 것을 나타내고 있다.

Table 4. Amino-type nitrogen and ammonia-type nitrogen contents of Chaga Cheonggukjang added with L. acidophilus KCTC 3925

$(\mathrm{mg} \%)$

\begin{tabular}{cccc}
\hline Samples $^{1)}$ & Control & NS & YS \\
\hline Amino-type nitrogen & $920.27 \pm 42.49^{2) \mathrm{a} 3)}$ & $884.80 \pm 65.12^{\mathrm{a}}$ & $837.20 \pm 8.40^{\mathrm{a}}$ \\
Ammonia-type nitrogen & $137.09 \pm 11.12^{\mathrm{b}}$ & $145.31 \pm 3.47^{\mathrm{b}}$ & $169.36 \pm 17.25^{\mathrm{a}}$ \\
\hline
\end{tabular}

${ }^{1)}$ Control, fermented without sterilization process and a starter; NS, fermented without sterilization process but with a starter ( $L$ acidophilus KCTC 3925 ); YS, fermented with $L$ acidophilus KCTC 3925 after sterilization process (at $100^{\circ} \mathrm{C}$ for $15 \mathrm{~min}$ ).

${ }^{2)}$ All values are mean $\pm \mathrm{SD}(\mathrm{n}=3)$.

${ }^{3) a b}$ Means with different superscripts in the same row are significantly different at $p<0.05$ by Duncan's multiple range test.

\section{Isoflavone 분석}

식물계에 널리 존재하는 diphenol 화합물인 isoflavone은 체내 이용률이 비교적 낮은 배당체인 genistin, daidzin, glycitin과 체내 이용률이 비교적 높은 비배당체인 genistein, daidzein, glycitein 등의 형태로 존재하는데, 대두를 충분히 발효시키면 대부분의 isoflavone은 비배당체로 전환되며 대 두에 수침이나 가열 등의 가공처리를 하면 용출된 $\beta$ -glycosidase의 작용에 의해 배당체에서 비배당체로 전환되 는 것으로 알려져 있다 $(32,34)$. 다른 콩 발효식품은 발효와 숙성기간이 수 개월 소모되는데 반하여 청국장 제조시에는 2-3일로 매우 단기간 발효되어 비배당체 이소플라본 생성 은 제한적으로 나타난다. 따라서, 본 연구에서는 isoflavone 비배당체 함량을 높이고자 Kim 등(9)이 보고한 이소플라본 비배당체 함량을 높이는 것으로 확인된 $\beta$-glycosidase 활성 이 우수한 $L$ acidophilus를 첨가하여 발효함으로써 비배당 체 함량 증가를 유도하였다(Table 5). 비배당체 이소플라본 함량은 control군 $666.84 \mu \mathrm{g} / \mathrm{g}$, NS군 $733.36 \mu \mathrm{g} / \mathrm{g}$, YS군 $851.48 \mathrm{\mu g} / \mathrm{g}$ 으로 나타나서 YS군이 유의적으로 가장 높게 나타났다(p<0.05). Kim 등(9)이 시간별로 L. acidophilus를 첨가하지 않은 된장의 이소플라본 비배당체 함량을 측정한 결과는 120 시간 후 daidzein은 $156.7 \mathrm{mg} / \mathrm{kg}$, glycitein은 86.7 $\mathrm{mg} / \mathrm{kg}$, genistein은 $104.3 \mathrm{mg} / \mathrm{kg}$ 으로 측정된 반면, $L$. acidophilus를 종균으로 첨가한 된장은 120시간 후 daidzein 은 $3017.7 \mathrm{mg} / \mathrm{kg}$, glycitein은 $576.7 \mathrm{mg} / \mathrm{kg}$, genistein은 663.7 $\mathrm{mg} / \mathrm{kg}$ 으로 측정되어 본 연구와 비슷한 경향을 나타내었다. 대두유를 제조할 때 $L$ acidophilus를 종균으로 사용시 배당 체 이소플라본이 비배당체 이소플라본으로 전환되는 것으 로 보고되었다(7,8). Donkor와 $\operatorname{Shah}(7)$ 의 보고에서는 $L$. acidophilus를 넣어 시간별로 발효시킨 두유에서 36시간 발 효시켰을 때 가장 이소플라본 비배당체 함량이 높았지만 추가적인 발효기간 연장에서는 감소하는 양상을 보였다. 따라서 기능성 향상을 위한 L acidophilus균 접종은 발효기 간이 몇 달에서 몇 년이 걸리는 된장, 간장과 같은 대두 발효식품보다는 전통대두발효식품 중 짧은 기간(2-3일)에 발효가 끝나는 청국장에 적합하다고 생각된다. 따라서 발 효시간을 최적화 하는 조건을 적용한다면 더 높은 비배당체 이소플라본 함량을 갖는 청국장을 얻을 수 있을 것이다. 한편, Yang 등(35)은 대두의 식품 제조공정 중 비배당체 형태를 증가시키기 위해서는 고온처리 과정이나 염산 $(\mathrm{HCl})$ 에 의한 산 가수분해방법보다는 $\beta$-glucosidase 활성을 활용 하는 것이 효율적이라고 제안하였다. 이는 고온이나 강산 을 이용한 경우 반응산물이 무작위적이고, 부반응에 의해 효율이 저하될 수 있는 반면, 천연물 유래 $\beta$-glucosidase를 활용하는 경우 반응산물의 선택성을 증가시킬 수 있으며 유해한 유기용매의 사용을 감소시키는 장점이 있다고 강조 하였다. 따라서 $L$ acidophilus균의 높은 $\beta$-glucosidase 활성 을 이용한다면 대두 발효식품 제조 시 제품의 기능성 향상 과 제품의 안정성 확보에 도움이 될 것으로 사료된다.

Table 5. Isoflavone aglycone contents of Chaga Cheonggukjang added with $L$. acidophilus KCTC 3925

(ppm)

\begin{tabular}{ccccc}
\hline \multirow{2}{*}{ Samples $^{1)}$} & \multicolumn{4}{c}{ Amount of isoflavone aglycone } \\
\cline { 2 - 5 } & Daidzein & Glycitein & Genistein & Sum \\
\hline Control & $323.22 \pm 11.04^{2)(3)}$ & $64.04 \pm 1.93^{\mathrm{b}}$ & $279.57 \pm 9.65^{\mathrm{c}}$ & $666.84 \pm 22.59^{\mathrm{c}}$ \\
NS & $349.62 \pm 2.70^{\mathrm{b}}$ & $68.02 \pm 0.98^{\mathrm{b}}$ & $315.72 \pm 3.55^{\mathrm{b}}$ & $733.36 \pm 6.57^{\mathrm{b}}$ \\
YS & $407.19 \pm 14.88^{\mathrm{a}}$ & $74.79 \pm 2.77^{\mathrm{a}}$ & $369.49 \pm 12.79^{\mathrm{a}}$ & $851.48 \pm 30.38^{\mathrm{a}}$ \\
\hline
\end{tabular}

${ }^{11}$ Control, fermented without sterilization process and a starter; NS, fermented without sterilization process but with a starter ( $L$ acidophilus KCTC 3925); YS, fermented with $L$ acidophilus $\mathrm{KCTC} 3925$ after sterilization process (at $100^{\circ} \mathrm{C}$ for $15 \mathrm{~min}$ ). ${ }^{2)}$ All values are mean $\pm \mathrm{SD}(\mathrm{n}=3)$.

${ }^{3 \text { al- }}$ Means with different superscripts in the same row are significantly different at $\mathrm{p}<0.05$ by Duncan's multiple range test.

\section{요 약}

차가버섯 청국장(control), 멸균된 청국장에 $L$. acidophilus KCTC 3925균을 접종하여 발효시킨 청국장 (NS)과 L. acidophilus KCTC 3925를 접종하기 전 유산균주 의 활성을 높이기 위해 멸균하여 잡균을 제거한 청국장(YS) 의 품질 특성과 이소플라본의 변화를 비교하였다. 수분함 량은 control군이 $51.44 \%, \mathrm{NS}$ 군이 $49.79 \%$, YS군이 $49.83 \%$ 였으며, 조회분은 control 군이 $4.57 \%, \mathrm{NS}$ 군이 $4.72 \%$, YS군 이 $4.54 \%$ 로 나타났고, 수분함량은 control군이, 조회분은 $\mathrm{NS}$ 군이 유의적으로 높았으며, $\mathrm{pH}$ 는 control군이 높았다. 
조단백은 control군이 $44.37 \%, \mathrm{NS}$ 군이 $43.21 \%, \mathrm{YS}$ 군이 $43.82 \%$ 로 나타나서 군들 간 유의적인 차이가 없었고, 조지 방은 control군이 $13.65 \%, \mathrm{NS}$ 군이 $12.60 \%, \mathrm{YS}$ 군이 $11.58 \%$ 로 control군이 유의적으로 높았다. 탄수화물은 control군이 $37.41 \%, \mathrm{NS}$ 군이 $39.47 \%$, YS군이 $40.07 \%$ 로 $\mathrm{YS}$ 군이 가장 높았고 식이섬유는 control군이 $33.82 \%, \mathrm{NS}$ 군이 $31.92 \%$, $\mathrm{YS}$ 군이 $32.63 \%$ 로 유의적인 차이가 없었다. 무기질 함량은 칼슘은 control군이 $275.16 \mathrm{mg} \%$, NS군이 $326.09 \mathrm{mg} \%$, YS 군이 $253.69 \mathrm{mg} \%$ 로 $\mathrm{NS}$ 군이 높았고, 인은 control군이 $691.20 \mathrm{mg} \%, \mathrm{NS}$ 군이 $676.44 \mathrm{mg} \%$, YS군이 $619.37 \mathrm{mg} \%$ 로 나타나서 control군이 높았다. 칼륨은 각각 $1,792.86 \mathrm{mg} \%$, $1,824.39 \mathrm{mg} \%, 1,813.09 \mathrm{mg} \%$ 로 유의적인 차이가 없었으며, 나트륨은 각각 $5.43 \mathrm{mg} \%, 9.64 \mathrm{mg} \%, 7.75 \mathrm{mg} \%$ 로 NS군이 유의적으로 높았고, 철은 각각 $110.59 \mathrm{mg} \%, 98.98 \mathrm{mg} \%$, $92.59 \mathrm{mg} \%$ 로 control군이 높게 나타났다. 카드뮴은 세 가지 청국장 모두 허용수치인 $0.02 \mathrm{mg} \%$ 를 초과하지 않았다. 유 리아미노산 함량은 $\mathrm{NS}$ 군과 $\mathrm{YS}$ 군이 각각 $2,520.92 \mathrm{mg} \%$, $2,421.94 \mathrm{mg} \%$ 로 control군에 비해 높게 나타났다. 아미노태 질소는 control군이 $920.27 \mathrm{mg} \%$, NS군이 $884.80 \mathrm{mg} \%$, YS 군이 $837.20 \mathrm{mg} \%$ 로 나타나서 control군이 가장 높았으며 암모니아태 질소는 control군이 $137.09 \mathrm{mg} \%, \mathrm{NS}$ 군이 $145.31 \mathrm{mg} \%$, YS군이 $169.36 \mathrm{mg} \%$ 로 YS군이 가장 높았다. 이소플라본 비배당체 총 함량은 control군이 $666.84 \mathrm{\mu g} / \mathrm{g}$, $\mathrm{NS}$ 군이 $733.36 \mu \mathrm{g} / \mathrm{g}$, YS군이 $851.48 \mu \mathrm{g} / \mathrm{g}$ 으로 YS군이 유의 적으로 가장 높았다. 따라서 본 연구를 통해 $L$ acidophilus $\mathrm{KCTC} 3925$ 균을 첨가한 차가버섯 청국장은 다른 청국장들 에 비해 품질특성면에서 별 차이가 없었으며, L acidophilus KCTC 3925 를 종균으로 이용한 2차 발효시 청국장 제품에 서 이소플라본 비배당체 함량을 증가시켜 품질적인 면이나 기능적인 측면에서 우수한 청국장 제조가 가능하였다.

\section{감사의 글}

본 논문은 중소벤처기업부에서 지원하는 2016년도 산학 연협력기술개발사업(No. C0442776)의 연구수행으로 인한 결과물임을 밝힙니다.

\section{References}

1. Hong JY, Kim EJ, Shin SR, Kim TW, Lee IJ, Yoon KY (2008) Physicochemical properties of Cheonggukjang containing Korean red ginseng and Rubus coreanum. Korean J Food Preserv, 6, 872-877

2. Jung YK, Lee YK, No HK, Kim SD (2006) Effect of chitosan on quality characteristics of Chungkukjang. J
Korean Soc Food Sci Nutr, 35, 476-481

3. Kim SH, Yang JL, Song YS (1999) Physiological functions of Chongkukjang. Food Ind Nutr, 4, 40-46

4. Lee JO, Ha SD, Kim AJ, Yuh CS, Bang IS, Park SH (2005) Industrial application and physiological functions of Chongkukjang. Food Science and Industry, 38, 69-78

5. Kim HJ, Lee SG, Ji YJ, Hwangbo MH, Lee EJ, Lee SP, Lee IS (2008) Quality characteristics of defatted soybean grits fermented by Bacillus subtilis NUC1. J Korean Soc Food Sci Nutr, 37, 1479-1484

6. Kiyosawa I, Matsuyama J, Arai C, Setoguchi T (1995) Suppressive effects of the methanol extracts from soybean products on SOS response of Salmonella typhimurium induced by mutagens and their contents of isoflavones. Nippon Shokuhin Kagaku Kaishi, 42, 835-842

7. Donkor ON, Shah NP (2008) Production of B-glucosidase and hydrolysis of isoflavone phytoestrogens by Lactobaillus acidophilus, Bifidobacterium lactis, and Lactobacillus casei in soy-milk. J Food Sci, 73, M15-M20

8. Kim IB, Shin S, Lim BL, Seong GS, Lee YE (2010) Bioconversion of soybean isoflavone by Lactobaillus plantarum and Bifidobacterium longum. Korean J Food Cookery Sci, 26, 214-219

9. Kim JS, Lee JH, Surh JH, Kang SA, Jang KH (2016) Aglycone isoflavones and exopolysaccharides produced by Lactobacillus acidophilus in fermented soybean paste. Nutr Food Sci, 21, 177-123

10. Kim JH, Park LY, Lee SH (2012) Fermentation and quality characteristics of Cheonggukjang with Chinese cabbage. Korean J Food Preserv, 19, 659-664

11. Jung YK, Lee YK, No HK, Kim SD (2006) Effect of sea tangle on fermentation and quality characteristics of Cheonggukjang. Korean J Food Preserv, 13, 95-101

12. Hwang SH, Chung HS, Kim SD, Youn KS (2004) Effect of Glycyrrhizia uralensis extract addition on the quality of Cheonggukjang. J East Asian Soc Diet Life, 14, 571-575

13. Park HY, Cho EJ (2008) Radical scavenging effects and physicochemical properties of Seolitae chungkukjang added with green tea. J Korean Soc Food Sci Nutr, 37, 401-404

14. Lee SH, Park SH, Lee KH, Park SJ, Kim YH (2011) Effect of Inonotus obliquus extract on the expression MMPs and HAS-2. J Soc Cosmet Sci Korea, 37, 237-245

15. Park KM (2008) Industrialization of mushroom functional substances. J Mushroom Sci Prod, 6, 1-12 16. AOAC (1996) Official methods of analysis. $15^{\text {th }} \mathrm{ed}$, 
Association of Official Analytical Chemists, Washington DC, USA, p 210-219

17. Koh EM, Jang KH, Surh JH (2014) Improvement of physicochemical properties of cereal based ready-to-eat Sunsik using fermentation with Bionuruk and Bifidobacterium longum. Food Sci Biotechnol, 23, 1977-1985

18. Choi HS, Joo SJ, Yoon HS, Kim KS, Song IG, Min KB (2007) Quality characteristics of Hwangki (Astragalus membranaceus) cheonggukjang during fermentation. Korean J Food Preserv, 14, 356-363

19. Hwang HA, Lee NK, Cho IJ, Hahm YT, Kwon KO, Kim BY (2008) Selection of microorganism and optimization of manufacture process for Cheonggukjang. Korean J Food Sci Technol, 40, 406-411

20. Kim JW, Kim YS, Jeong PH, Kim HE, Shin DH (2006) Physicochemical characteristics of traditional fermented soybean products manufactured in folk villages of Sunchang region. J Food Hyg Saf, 21, 223-230

21. Park NY, Seong JH, Choi MS, Moon KD, Kwon JH, Jeong YJ (2008) Comparison of functional properties of Cheonggukjang by using red ginseng. J Korean Soc Food Sci Nutr, 37, 261-268

22. Food composition table (2017) National standard food composition table. $9^{\text {th }}$ ed, Rural Development Administration, Jeonju, Korea, p 428-429

23. Kang SJ, Kim SS, Chung HY (2014) Comparison of physicochemical characteristics and consumer perception of Cheongkukjang. J Korean Soc Food Sci Nutr, 43, 1104-1111

24. Lee SD, Lee YK, Kim MS, Park SK, Kim YS, Chae YZ (2012) The content and risk assessment of heavy metals in herbal pills. J Food Hyg Saf, 27, 375-387

25. Yoo SM, Choe JS, Park HJ, Hong SP, Chang CM, Kim JS (1998) Physicochemical properties of traditional Chonggugjang produced in different regions. Appl Biol Chem, 41, 377-383

26. Beak LM, Kang KM, Park LY, Lee SH (2012) Fermentation and quality characteristics of Cheongkookjang prepared with germinated soybean. Korean J Food Preserv, 19, 547-553

27. Lee HJ, Cho SA, Shin JG, Kim JS, Jeong YJ, Moon KD, Kwon JH (2007) Quality and functional components of commercial Chungkukjang powders. J Korean Soc Food Sci Nutr, 36, 65-71

28. Lee GY, Kim SI, Jung MG, Seong JH, Lee YG, Kim HS, Chung HS, Lee BW, Kim DS (2014) Characteristics of Chungkookjang that enhance the flavor and GABA content in a mixed culture of Bacillus subtilis MC31 and Lactobacillus sakei 383. J Life Sci, 24, 1102-1109

29. Ju KE, Oh NS (2009) Effect of the mixed culture of Bacillus subtilis and Lactobacillus plantarum on the quality of Cheonggukjang. Korean J Food Sci Technol, 41, 399-404

30. Lee SY, Seo BY, Eom JS, Choi HS (2017) Quality characteristics of fermented soybean products produced by lactic acid bacteria isolated from traditional soybean paste. Korean J Food Preserv, 24, 187-195

31. Mann SY, Kim EA, Lee GY, Kim RU, Hwang DY, Son HJ, Lee BW, Lee CY, Kim DS (2013) Characteristics of Chungkookjang produced by Bacillus subtillus MC31. J Life Sci, 23, 560-568

32. Lee KH, Choi HS, Hwang KA, Song J (2015) Changes in isoflavone content and quality characteristics of Cheonggukjang prepared by some different strains. J Korean Soc Int Agric, 27, 481-488

33. Eom SM, Jung BY, Oh HI (2009) Changes in chemical components of Cheonggukjang prepared with germinated soybeans during fermentation. J Appl Biol Chem, 52, 133-141

34. Ko HM, Choi SJ, Choi WS, Lee NH, Choi UK (2014) Quality characteristics of Cheonggukjang made with the smoked soybeans. J Korean Soc Food Sci Nutr, 27, 274-279

35. Yang SO, Chang PS, Baek BK, Hong SD, Lee JH (2007) Changes of isoflavone distribution in soybean using almond powder. Korean J Food Sci Technol, 39, 231-236 